\begin{tabular}{l} 
POLITEIA Politeia: Jurnal Ilmu Politik \\
Politeia: Jurnal Ilmu Politik, 10 (1) (2018): 60-68 \\
ISSN 0216-9290 (Print), ISSN 2549-175X (Online) \\
Available online https://jurnal.usu.ac.id/index.php/politeia \\
\hline
\end{tabular}

\title{
Perilaku Pemilih Etnik Batak terhadap Pemilihan Kepala Daerah
}

\author{
Ika Ratna Sari* \& Warjio \\ Departemen Ilmu Politik, Fakultas Ilmu Sosial dan Politik \\ Universitas Sumatera Utara, Indonesia
}

Diterima Maret 2018; Disetujui Mei 2018; Dipublikasikan Juli 2018

\begin{abstract}
Abstrak
Artikel ini membahas tentang hubungan kesamaan marga/etnisitas dalam menentukan pilihannya. Masalah etnis/kesamaan marga merupakan masalah yang sering diperdebatkan di Indonesia "apakah masyarakat memilih berdasarkan etnis/kesamaan marga?". Inilah pertanyaan yang seringkali kita hadapi. Kerena kebanyakan masyarakat di Indonesia memilih berdasarkan satu suku/satu marga dengan calon pemimpin tersebut. Jenis penelitian yang digunakan dalam penelitian ini adalah jenis penelitian kualitatif yang berusaha memahami dan menafsirkan makna dari suatu peristiwa. Adapun data-data yang digunakan dalam penelitian ini adalah data-data berasal dari studi pustaka dan juga data-data dari lapangan yang diperoleh dengan menyebarkan angket atau kusioner kepada para pemilih di Kecamatan Balige. Dari hasil tersebut sebagian besar masyarakat pemilih di Kecamatan Balige memilih pasangan calon yang satu marga dan adanya hubungan kekerabatan dengan mereka. Hal ini terlihat jelas dari hasil pemungutan suara di daerah ini, dimana pasangan Kasmin Simanjuntak/Liberty Pasaribu yang menjadi pemenang. Dari data yang didapatkan penulis, bahwa sebagian besar yang memilih pasangan ini dikerenakan adanya faktor kesamaan marga/etnisitas dan faktor kekerabatan.
\end{abstract}

Kata kunci: Etnisitas, Partisiasi Politik, Perilaku Pemilih

\begin{abstract}
This article discusses about the relationship of clan/ethnicity in choosing. Ethnic problems / clan similarities are a problem that's often debated in Indonesia "do people choose based on ethnicity / clan similarity?". These are the questions that we often face. Because most people in Indonesia choose based on one tribe / one clan with the prospective leader. The type of research used in this study is a type of qualitative research that seeks to understand and interpret the meaning of an event. The data used in this study are data derived from library studies and also data from the field obtained by distributing questionnaires or questionnaires to voters in Balige District. From these results, most of the voters in the District of Balige chose the pairs of candidates who were one clan and a kinship with them. This is evident from the results of the voting in this area, where the couple Kasmin Simanjuntak / Liberty Pasaribu were the winners. From the data obtained by the author, the majority of those who chose this pair were subjected to the factors of clan / ethnicity and kinship factors.
\end{abstract}

Keyword: Ethnicity, Political Partitioning, Voter Behavior

How to Cite: Sari, I.K, \& Warjio. (2018). Perilaku Pemilih Etnik Batak terhadap Pemilihan Kepala Daerah, Politea: Jurnal Ilmu Politik, 10 (2): 60-.68.

*Corresponding author:

E-mail: ikaratnasari@gmail.com 


\section{PENDAHULUAN}

Partisipasi merupakan aspek yang penting dari demokrasi, dimana prinsip dasar demokrasi ialah setiap orang dapat ikut serta dalam proses pembuatan keputusan politik atau disebut kegiatan sekelompok orang yang akan turut serta secara aktif baik dalam kehidupan politik dengan jalan untuk memilih pemimpin secara langsung, dan juga dapat mempengaruhi kebijakan pemerintah. (Rahman, 2007)

Di negara-negara demokrasi konsep partisipasi politik bertolak dari paham bahwa kedaulatan ada di tangan rakyat, yang dilaksanakan melalui kegiatan bersama untuk menetapkan tujuan-tujuan serta masa depan masyarakat itu dan untuk menentukan orang-orang yang akan memegang tampuk pimpinan, sehingga partisipasi politik erat sekali kaitannya dengan kesadaran politik, kerena semakin sadar bahwa dirinya diperintah. (Budiardjo : 2008) .

Anggota masyarakat secara langsung memilih wakil-wakil yang akan duduk dilembaga pemerintahan. Dengan kata lain partisipasi langsung dari masyarakat yang seperti ini merupakan penyelenggaraan kekuasaan politik yang absah oleh rakyat. Keikutsertaan masyarakat dalam berpartisipasi sangatlah penting karena teori demokrasi menyebut bahwa perlunya partisipasi politik masyarakat pada dasarnya disebabkan bahwa masyarakat tersebut sangatlah mengetahui apa yang mereka kehendaki. (Budiardjo: 2008).

Partisipasi tidak hanya dibina oleh partai politik, tetapi juga melalui organisasi-organisasi yang mencakup golongan pemuda, golangan buruh, serta

kebudayaan

organisasi-organisasi pembinaan yang ketat potensi masyarakat dapat dimanfaatkan secara kendali. Ada faktor utama yang membentuk partisipasi di Indonesia salah satunya adalah faktor etnisitas/kesamaan marga. kelompaok etnis mempunyai peranan besar dalam membentuk sikap, persepsi, dan orientasi seseorang. Dengan adanya kesukuan atau kesamaan marga sehingga dapat mempengaruhi pilihannya.

Pemilihan Kepala Daerah Kabupaten Toba Samosir periode 2010-2015 yang lalu merupakan salah satu wujud demokrasi di mana semua masyarakat di Kabupaten Toba Samosir memiliki hak untuk memilih sendiri pemimpinnya secara langsung.

Sesuai dengan data yang diperoleh dari lembaga KPU Toba Samosir Secara keseluruhan jumlah suara yang terkumpul sesuai datadata suara sebanyak 59.405 suara. Sementara itu jumlah daftar pemilu tetap (DPT) pada pemilukada ini sebanyak 82.002 suara. Adapun jumlah pemilih dalam salinan daftar pemilu tetap (DPT) Yang tidak menggunakan hak suara nya sebanyak 15.372 suara, yang tidak sah sebanyak 7.225 suara. Dari total tersebut maka pelaksanaan pemilukada Kabupaten Toba Samosir satu putaran.

Untuk hasil pemilihan Kepala Daerah Kabupaten Toba Samosir, pasangan Kasmin Simanjuntak dengan Liberty Pasaribu memperoleh kemenangan mutlak daripada pasangan calon Bupati dan wakil bupati yang lain bahkan mengalahkan suara pasangan Monang Sitorus 
dengan Mangatas Silaen yang kita ketahui bahwa pasangan ini merupakan bupati Toba Samosir periode tahun 2005-2010 lalu

Dari studi-studi yang telah dilakukan oleh para mahasiswi Departemen Ilmu Politik sebelumnya ditemukan adanya hubungan kesamaan marga/etnisitas dalam menentukan pilihannya. Berangkat dari hasil penelitian tersebut saya kemukakan di atas maka saya tertarik untuk meneliti kembali pengaruh hubungan etnisitas/kesamaan marga dalam menentukan pilihannya, apakah Kecamatan Balige merupakan masyarakat yang memilih dengan tidak rasional atau memilih karena adanya faktor kesamaan etniitas/kesamaan marga dalam kemenangan pasangan Kasmin Simanjuntak dan Liberty Pasaribu.

\section{METODE PENELITIAN}

Jenis penelitian yang digunakan dalam penelitian ini adalah penelitian eksploratif. Dengan demikian akan melakukan penelitian dalam rangka penjajakan. Populasi adalah keseluruhan objek penelitian yang terdiri dari manusia, bendabenda, tumbuh-tumbuhan, gejala-gejala, nilai test atau peristiwa-peristiwa sebagai sumber data yang memiliki karakteristik tertentu di dalam suatu penelitian. Sedangkan sampel adalah sebagian dari populasi untuk mewakili seluruh populasi.(Nawawi, 1995).

Penelitian ini dilakukan di Kecamatan Balige, Kabupaten Toba Samosir. Data yang dikumpulkan dari penelitian ini berdasarkan dari hasil pembagian angket kepada 99 responden yang tinggal di Kecamatan Balige. Dari 99 responden yang ditemui berasal dari kalangan profesi yang berbeda, diantaranya berasal dari kalangan Pegawai Swasta, Mahasiswa, wiraswasta, Petani, Pegawai Negeri.

Dari data di dapat dalam hasil penelitian dapat diketahui bahwa faktor etnisitas/kesamaan marga atau hubungan kekerabatan sangat berpengaruh terhadap pilihan calon Kepala Daerah. Maka responden cenderung sebagai pemilih tradisional disebabkan kuatnya politik parochial ini dapat semakin kuat ketika dengan adanya calon-calon Kepala Daerah yang berasal dari marga-marga yang sama dengan responden. Secara kerangka teoritis dalam kegiatan ini dapat juga dianalisa menjadi pendekatan sosiologis dimana menurut pendekatan ini dalam kegiatan memilih dalam kaitan konteks sosial yang sangat kongkritnya dalam pilihan seseorang dalam Pemilihan Umum dipengaruhi oleh pengelompokan sosial seperti halnya agama dan kesamaan marga.

Alasan memilih pemilihan etnis Batak Toba sebagai populasi karena skripsi ini akan meneliti perilaku politik dari golongan etnis minoritas di dalam kegiatan politik yang diselenggarakan di dalam masyarakat yang mayoritas homogen. Pertanyaan selanjutnya ialah faktor apa yang menentukan pilihan oleh masyarakat etnis minoritas didalam lingkungan yang mayoritas homogen. Hal ini berlatarbelakang pada pasangan pasangan calon bupati/ wakil bupati yang kesemuanya berasal dari etnis mayoritas yang homogen.

Dalam penelitian ini digunakan teknik Purposive Sampling yaitu terdapatnya kriteria-kriteria yang perlu dilakukan ataupun dibuat 
batasan-batasan berdasarkan tujuantujuan tertentu sehingga sesuai dengan sumber daya yang tersedia namun tetap mencapai jumlah sampel yang ditetapkan. Kriteria-kriteria ataupun batasan-batasan yang yang dimaksud pada Purposive Sampling disini adalah bahwa sampel-sampel yang dikumpulkan adalah etnis Batak Toba.

Untuk memperoleh data atau informasi, keterangan-keterangan atau fakta-fakta yang diperlukan, maka penulis menggunakan teknik pengumpulan data sebagai berikut: 1) Data Primer : yaitu penelitian lapangan (field research), yaitu pengumpulan data dengan terjun langsung ke lokasi penelitian, dengan cara: a) Kuesioner/angket, yaitu suatu cara pengumpulan data dengan menyebarkan angket/kuesioner yang berisi daftar pertanyaan kepada responden. b) Wawancara, yaitu suatu cara pengumpulan data dengan dialog langsung dengan responden yang berhubungan dengan objek penelitian guna melengkapi data yang kurang jelas pada kuesioner/angket. 2) Data Sekunder: yaitu penelitian kepustakaan (Library Research), yaitu mempelajari buku-buku, peraturanperaturan, laporan-laporan serta bahan-bahan lain yang berhubungan dengan penelitian. Adapun teknik analisa data yang digunakan penulis dalam penelitian ini adalah menggunakan jenis analisa data kualitatif, dimana jenis analisa data seperti ini banyak dipergunakan dalam jenis penelitian Deskriptif, yaitu: suatu metode yang lebih didasarkan kepada pemberian gambaran yang terperinci yang mengutamakan penghayatan dan berusaha memahami suatu peristiwa dalam situasi tertentu menurut pandangan peneliti. Kemudian data yang ada dikelompokkan dan disajikan dalam bentuk tabel-tabel dan uraian. Jadi penulis hanya menganalisa dengan cara menggambarkan dta yang diperoleh dengan mengadakan atau memberi interpretasi.

\section{HASIL DAN PEMBAHASAN}

Setelah penelitian lapangan di lakukan dengan cara membacakan angket kepada responden, maka diperoleh berbagai data mengenai jawaban-jawaban responden terhadap beberapa pertanyaan yang diajukan dalam angket/kusioner sekaligus sikap ataupun perilaku responden terhadap pemilihan pasangan Kasmin Simanjuntak dan Liberty Pasaribu pada Pemilihan Umum Kepala Daerah Toba Samosir Tahun 2010. Data-data yang dibahas dalam bab ini diperoleh dari hasil penelitian lapangan yang dilakukan pada tanggal 3 Agustus hingga 13 Agustus 2011 (10 hari) di Kecamatan Balige, Kabupaten Toba Samosir, Provinsi Sumatera Utara.

Perilaku pemilih etnis Batak Toba pada Pemilihan Kepala Daerah 2010 yang lalu cenderung memilih berdasarkan atas kesamaan marga atau unsur kekerabatan. Sikap seperti ini merupakan suatu sikap yang mementingkan diri sendiri. Memang dalam adat istiadat Batak Toba dikatakan Dang tumangonan tu halak molo adong dihita (jika dari kita masih ada buat apa memilih orang lain), namun seharusnya dalam pelaksanaannya harus lebih melihat dari kualitas calon. Buat apa memilih yang satu etnis/kesamaa marga dengan kita, tetapi kualitas yang 
dimiliki tidak ada. Perilaku dari masyarakat yang seperti inilah yang mengakibatkan adanya suatu kegagalan politik.

Jumlah responden yang berusia 41-50 Tahun dan juga berusia 51 Tahun keatas lebih banyak mendominasi penelitian ini jika dibandingkan usia responden lain yang tergolong masih muda, khususnya pemilih pemula yang berusia 17 Tahun. Hal ini dikarenakan penelitian selalu dilakukan menjelang siang hari yaitu sekitar pukul 10:00 WIB di mana para pemilih muda yang terdapat pada klasifikasi pemilih usia 17-30 Tahun sedang melakukan kegiatan belajar di sekolah. Selain itu kebanyakan penduduk Kecamatan Balige usia sekolah melanjutkan pendidikan di luar Kecamatan Balige. Hal ini menjadi kendala untuk melakukan wawancara melalui angket/kuesioner kepada para pemilih pemula tersebut.

Partisipasi politik penduduk Kecamatan Balige dalam Pemilihan Umum Kepala Daerah Kabupaten Toba Samosir Tahun 2010 lebih banyak didominasikan oleh pemilih yang berjenis kelamin perempuan sebanyak dibandingkan pemilih yang berjenis kelamin laki-laki. Hal ini dinilai wajar dikarena pada Tabel 1 dan Tabel 2 yang telah dibahas pada Bab II juga menunjukan bahwa pemilih Tetap di Kecamatan Balige lebih didominasi oleh pemilih tetap yang berjenis kelamin Perempuan.

Pemilihan di Kecamatan Balige lebih banyak didominasi oleh pemilih yang beragama Kristen Protestan. Dapat kita simpulkan bahwa tingkat partisipasi politik pemilih yang beragama Kristen Protestan di Kecamatan Balige dalam Pemilihan
Umum Kepala Daerah Kabupaten Balige Tahun 2010 lebih tinggi dibandingkan dengan pemilih yang beragama Kristen Katolik maupan beragama Islam. Hal ini dinilai wajar karena mayoritas penduduk di Kecamatan Balige merupakan pemeluk agama Kristen Protestan, yaitu sebanyak 32.142 jiwa penduduk

Penduduk di Kecamatan Balige lebih banyak didominasi oleh penduduk yang berpendidikan SMA/Sederajat jika dibandingkan dengan tingkat pendidikan lainnya. Melalui data dalam tabel diatas maka dapat kita simpulkan bahwa penduduk Kecamatan Balige yang berpendidikan SMA/Sederajat lebih banyak menggunakan hak pilihnya dalam Pemilihan Umum Kepala Daerah Kabupaten Toba Samosir Tahun 2010.

Suku Batak Toba lebih tinggi tingkat partisipasi politiknya dan lebih dominan dalam memberikan suara pada Pemilihan Umum Kepala Daerah Kabupaten Toba Samosir Tahun 2010 jika dibandingkan dengan suku-suku lain yang terdapat di Kecamatan Balige. Hal ini dipandang wajar karena Suku Batak Toba adalah merupakan penduduk mayoritas di Kecamatan Balige.

\section{Analisis Jawaban Responden Evaluasi Tentang Partisipasi}

Secara keseluruhan, masyarakat pemilih di Kecamatan Balige setuju dengan pelaksanaan pemilihan Kepala Daerah/Wakil Kepala Daerah secara langsung yang dilaksanakan diberbagai daerah Indonesia. Adapun yang menjadi alasan dari masyarakat di Kecamatan ini yaitu dengan adanya pemilihan kepala daerah secara langsung maka masyarakat dapat 
lebih mengenal sosok calon kepala daerah yang akan memimpin daerah mereka. Rakyat yang lebih mengetahui siapa yang layak ataupun pantas memimpin mereka karena dalam Negara demokrasi kekuasaan tertinggi ada di tangan rakyat.

Masyarakat pemilih di Kecamatan Balige cenderung aktif dalam setiap Pemilihan Umum, sebagian besar responden menjawab lebih dari tiga kali. Hal seperti ini menunjukan bahwa tingkat partisipasi dalam Pemilihan Umum Kepala Daerah di Kecamatan Balige sudah termasuk cukup tinggi.

Sebagian besar responden di Kecamatan Balige memilih alasan menggunakan hak pilihnya dikerenakan selaku warga Negara Indonesia (WNI), responden beranggapan bahwa pemilihan Kepala Daerah adalah suatu rutinitas yang dilaksanakan 5 Tahun sekali, dan sebagian lagi dikarenakan masyarakat di Kecamatan Balige meminta adanya perubahan-perubahan yang baik di kabupaten.

Sebagian besar responden mengetahui calon kandidat Kapala Daerah mereka melalui Baliho/Spanduk/Stiker. Karena media inilah yang sering disaksikan/dijumpai oleh masyarakat walaupun sebenarnya dengan melihat atau menyaksikan belum tentu mempengaruhi perilaku pemilih di Kecamatan Balige.

Masyarakat pemilih di

Kecamatan Balige cenderung memilih berdasarkan hubungan saudara/marga dengan responden sebanyak 64,65\% merupakan Pemilih Tradisional dimana pemilih ini sangat mengutamakan kedekatan sosial-budaya, nilai, asal-usul, faham, dan agama sebagai ukuran untuk memilih suatu calon Kepala Daerah, seperti yang dijelaskan dalam Bab I ada suatu istilah dalam diri batak toba yaitu Dalihan Natolu, yang terdiri atas 3 bagian yakni: Somba marhulahula (harus menghoramati saudara dari pihak ibu, ibunya bapak kita, maupun dari pihak istri kita), Elek Marboru( menyanyangi saudara kandung perempuan), Manat Mardongan Tubu ( menghargai dan menghormati teman 1 marga kita) serta adanya istilah Dang Tumagonan Tu Halak adong do di Hita ( buat apa memilih orang lain, yang dalam hal ini yang tidak satu suku ataupun semarga dengannya jika dari suku/semarga kita sendiri masih ada). Hal seperti ini juga yang diterapkan masyarakat Kecamatan Balige pada Pilkada Tahun 2010 yang lalu.

Hubungan saudara/kesamaan marga dari Kasmin Simanjuntak dan Liberty Pasaribu, merupakan faktor paling dominan dalam mempengaruhi sebagian penduduk Kecamatan Balige untuk memilih mereka, sedangkan partai-partai pendukung, visi-misi serta figur bukanlah faktor utama yang mempengaruhi mereka dalam menentukan pilihannya ini menunjukan bahwa responden merupakan Pemilih Tradisional, dimana pemilih tradisional sangat mengutamakan kedekatan sosial budaya, nilai, asal-usul faham, dan agama sebagai tolak ukur untuk memilih calon pemimpinnya. Kebijakan semisal visi-misi, partaipartai pendukung dianggap sebagai parameter kedua.

Masyarakat pemilih di Kecamatan Balige secara garis besar 
belum mengerti akan apa yang dimaksudkan dengan partisipasi politik. Hal seperti ini menunjukan suatu kemajuan yang sangat pesat dalam bidang politik. Masyarakat tidak lagi bersikap pasif seperti di era orde baru sehingga masyarakat gampang dipengaruhi oleh pihak. Namun masih banyak masyarakat Kecamatan Balige menjatuhkan pilihannya kepada calon yang mempunyai kesamaan Suku/Marga, menurut responden apabila calon Kepala Daerah tersebut menang atau menjadi Kepala Daerah ada rasa kebanggaan dan rasa kepuasaan tersendiri.

\section{Evaluasi Tentang Etnisitas}

Masyarakat pemilih di Kecamatan Balige menjawab bahwa faktor kesamaan marga sangat berpengaruh terhadap pilihannya, responden berangangap apabila calon Kepala Daerah yang mempunyai kesamaan Marga/Etnis dengannya menjadi Kepala Daerah ada rasa kebanggaan dan kepuasaan didalam diri mereka. Masyarakat pemilih di Kecamatan Balige cenderung memilih berdasarkan kesamaan marga seperti yang dijelaskan pada Bab I dimana ada istilah dalam diri Batak Toba yang mengatakan Dang tumangonan tu halak molo adong do di hita ( buat apa memilih orang lain, yang dalam hal ini yang tidak satu marga/ kesamaan marga dengannya jika dari marga kita sendiri masih ada). Hal ini juga yang diterapkan oleh sebagian besar dari masyarakat Kecamatan Balige pada Pemilihan Kepala Daerah Tahun 2010 yang lalu. Faktor agama juga dapat mempengaruhi responden dalam menentukan pilihannya pada
Pemilihan Kepala Daerah Kabupaten Toba Samosir Tahun 2010 yang lalu.

Sebagian besar responden merupakan pemilih tradisional, dimana pemilih seperti ini sangat mengutamakan kedekatan sosial, budaya, nilai, asal -usul, faham, dan agama sebagai tolak ukur untuk memilih suatu partai politik atau memilih Kepala Daerah.

Setelah terkumpul data-data yang diperlukan, maka langkah selanjutnya adalah menganalisis data. Pada tahap ini sasaran utama adalah mengetahui bagaimana sesungguhnya perilaku pemilih etnis yang ada di Kecamatan Balige. Pilihan merupakan salah satu aspek dari perilaku secara umum. Perilaku baik secara umum ataupun perilaku pada wilayah yang lebih spesifik seperti politik merupakan hasil dari proses interaksi sosial yang cukup kompleks. Interaksi itu melibatkan banyak hal, mulai dari bentuk interaksi, karekter lingkungan dan juga karakter masyarakat. Dalam interaksi sosial, terdapat berbagai stimulus yang akan berbeda-beda. Perilaku politik juga berupa proses yang melibatkan berbagai hal.

Dari hasil data-data yang terkumpul masyarakat Kecamatan Balige mempunyai tingkat partisipasi yang cukup tinggi dimana masyarakat Kecamatan Balige sangat merespon pemilihan Kepala Daerah, serta hasil yang saya temukan bahwa faktor etnisitas/ kesamaan marga dari seorang calon Kepala Daerah sangat berpengaruh dalam menentukan pilihannya, ini dikarenakan masih tingginya nilai-nilai tradisional dimana ada istilah Dalam adat istiadat batak toba dikenal istilah Dalihan Natolu, yang terdiri atas 3 bagian yakni: Somba marhula-hula yang berarti 
kita harus menghormati saudara lakilaki dari pihak ibu, ibunya bapak kita, maupun dari pihak istri kita. Hulahula merupakan pihak yang sangat berpengaruh dalam adat istiadat etnis batak toba. Elek Marboru, yang berarti kita harus menyanyangi saudara kandung perempuan ataupun saudara perempuan dari pihak ayah kita. Manat Mardongan Tubu, yang berarti kita harus menghargai dan menghormati teman 1 marga kia. Kita tidak bisa menyinggung perasaannya atau bahkan menyakiti hatinya karena dia sama dengan saudara kandung kita sendiri. Ketiga bagian ini saling berhubungan satu sama lain, yang mengatur hak dan kewajiban masingmasing anggota masyarakat etnis batak toba dan juga ada istilah bagi orang batak toba, Dang Tumangonan Tu Halak adong do di hita ( buat apa memilih orang lain kalau masih ada dari kita sendiri).

Adapun responden yang memilih pilihan Kepala Daerah dengan faktor kesamaan marga memiliki alasan apabila Kepala Daerah tersebut memiliki kesamaan marga atau memiliki hubungan kekerabatan ada rasa kebanggaan tersendiri serta kepuasan di dalam diri mereka.

\section{SIMPULAN}

Dalam

menjatuhkan pilihannya, masyarakat di Kecamatan Balige tergolong dalam pilihan yang tidak rasional, karena masyarakat di Kecamatan Balige menjatuhkan pilihannya kerena adanya kesamaan etnisitas kesamaan marga serta faktorfaktor lain, contohnya: terpengaruh oleh orang lain dan lain-lain.

\section{DAFTAR PUSTAKA}

Abdullah, H.R, (2005). Pelaksanaan Otonomi luas dengan pemilihan kepala daerah secara langsung, Jakarta: Raja Gravido persada.

Aminah, S. (2014). Kuasa Negara pada ranah politik local, Jakarta: Predana Media Grup.

Runua, N. (1994). Dinamika Politik Indonesia. Dari Pemilu 1992 Sampai Kabinet Pembangunan VI. Jakarta: Bima Rena Pariwara.

Asfar, M. (2006). Pemilu dan Perilaku Memilih 1955-2004. Pustaka Eureka.

Budiardjo, M. (2008). Dasar-Dasar Ilmu Politik Edisi Revisi. Jakarta : Gramedia.

Firmanzah. (2007). Marketing Politik. Jakarta: Yayasan Obor Indonesia..

Horald, F.G.. (1934). Ensyklopedia Of The Social Science. New York : Mc Grew Hill Book Company.

https://nasional.tempo.co/read/news/2 016/02/25/173748047/ peneliti-lipiada-upaya-menggeser-ideologidari-pancasila. Diakses pada Tanggal 25 Februari 2016

Prihatmoko, J.J. (2005). Pemilihan Kepala Daerah Langsung : Filosofi, sistem dan problema penerapan di Indonesia. Yogyakarta: Pustaka

Latif, Y. (2015). Negara Paripurna Historitas, Rasionalitas, dan Aktualitas Pancasila. Jakarta: PT. Gramedia Pustaka Utama.

Marijan, K. (2010). Sistem Politik Indonesia: Konsolidasi Demokrasi Pascaorde Baru. Jakarta: Kencana Prenada Media Grup.

Ahmadi, A. (1979). Psikologi Sosial. Surabaya: PT Bina Ilmu.

Ahmad, A. (2005). Pilkada Langsung dan Masa Depan Demokrasi, Averroes Press.

Rahardjo \& Dawam, M,. (1996). Intelektual Inteligensia Dan Perilaku Politik Bangsa. Bandung: Mizan.

Siagian, M. (2011). Metode Penelitian Sosial (Pedoman Praktek Penelitian Bidan 
Ilmu-ilmu Sosial dan Kesehatan). Medan: PT Grasindo Monoratama.

Singarimbun, M. (2006). Metode Penelitian Survei. Jakarta: LP3ES.

Martono, N. (2010). Metode Penelitian Kuantitatif, Analisis Data Sekunder, Jakarta: Rajawali Press.

Thubany, S.H. (2005). Pilkada BIMA 2005:

Era Baru Demokratisasi Lokal
Indonesia. Yogyakarta: Gramedia Pustaka.

Takwin, B. (2003). Akar-akar Ideologi: Pengantar Kajian Konsep Ideologi dari Plato hingga Bourdieu. Yogyakarta; Jalasutra.

Zuriah, N. (2002). Revitalisasi - Radikalisasi Filsafat Dan Ideologi Pancasila Di Era Reformasi-Globalisasi. Malang. 